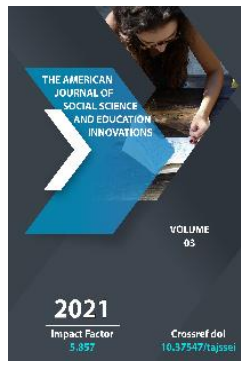

Journal Website: http://usajournalshub.c om/index,php/tajssei

Copyright: Original content from this work may be used under the terms of the creative commons attributes 4.0 licence.

\section{Criteria For Assessing The Basic Competences Of The Modern} Teacher

\author{
Sabitova Kamola Furqatovna \\ 2nd Year Master's Degree In History, TSPU, Tashkent, Uzbekistan \\ Tokhtayeva Fazilat Shavkat qizi \\ 2nd Year Master's Degree In Information Technology In Education, TSPU, Tashkent, Uzbekistan
}

Abduxalilova Dilfuza Maxsutaliyevna

Namangan Institute Of Civil Engineering, Independent Researcher, Namangan, Uzbekistan

\title{
ABSTRACT
}

In the article, the author discusses the essence of the basic competencies of modern students. He also demonstrated how to assess basic competencies from a historical perspective and analyzed the process empirically.

\section{KEYWORDS}

Learning process, critical thinking, basic competence, logic, innovative technologies, assessment, historical event, criteria, competencies, analysis and synthesis, analysis, feedback, method, qualification, teacher, analysis.

\section{INTRODUCTION}

In recent years, as in all areas of the country, measures are being taken to radically reform the education system. In particular, the introduction of a competency-based approach in the Ministry of Higher and Secondary Special
Education of the Republic of Uzbekistan and the development of state educational standards based on it. 
The President of the Republic of Uzbekistan Sh.M.Mirziyoev said, "It is very important to solve another problem: it is the professional level of teachers and professors, their special knowledge. In this regard, it is necessary to create an environment that actively contributes to the process of education, spiritual enlightenment and the formation of true values "[1], which is confirmed today. Nowadays, the requirements for modern lessons and teachers are changing. Students should be able to apply their knowledge in situations that they may encounter in their daily lives. A competency-based approach to education was chosen as the methodological basis for thinking about this.

Basic competencies in order to ensure consistency of the content of general education subjects taught in general secondary, secondary special, vocational education, based on the continuity of education in the Republic of Uzbekistan, aimed at educating a harmoniously developed person and specific competencies were identified based on the content of each subject.

Determining whether a modern teacher has the core competencies or how well he or she applies them to the educational process is important to us to improve the quality and effectiveness of the lesson. In this case, we need to identify the shortcomings of the teacher, that is, the basic competencies that are weakened as a result of our study. At this point, the criteria for evaluating education based on the competency approach are the knowledge, skills and abilities acquired by students. $z$ is education aimed at the formation of competencies for practical application in personal, professional and social activities.b means that we need methodological assistance to overcome it. Assessment of a teacher's core competencies can usually be done by the school administration, methodologists, or other educators.

In addressing this topic, a number of Uzbek scholars have conducted research, in particular the "Assessment of Skills and Competences" Yusupova A.A. and Kamolova SR [2], "Pedagogical competence as an important factor in the teaching process" Rakhimov Zokir scientific article [3], "Introduction of state educational standards based on competency approach - as a modern educational paradigm" Vakhobov M. M [ 4], Usarov Jabbor Eshbekovich's dissertation on "Improving the content of education and developing students' competence on the basis of basic and scientific competencies (on the example of teaching physics)" [5].

Many studies by Russian scientists on the subject are also important. For example, E.E. Feyushina's book, How to Assess the Competence of a Teacher, [6] shows how to assess teacher competence through testing and diagnostic methods in solving a professional problem. K. V. Semenovaesa in her article "The program of assessment of competence of teachers: what is this and the term of performance" divides the definition of teacher comet into three stages. In this case, the diagnostic work shows the methods of implementation through the analysis of questionnaires and lesson videos. [7]

Let's not talk about competence and basic competence.

Competence is the readiness of an entity to set a goal and effectively use external and internal resources to achieve it, in other words, it is 
related to the subject's specific object of activity. is a personal ability to solve problems successfully.

Competence is the transcendence of social requirements (norms) for a student's predefined educational preparation required for effective creative activity in a particular field. [8]

\section{MAIN PART}

There is no single list of core competencies in the world. Because each country or region has its own traditions, mentality and unique requirements. Competence is a social order that society places on its citizens, the list of which is determined by the social environment in a particular country or region. Such an agreement is not always possible. For example, in the Swiss and United States Organization for Economic Cooperation and Development and the National Institute of Educational Statistics, the project "Selection and Identification of Basic Competences" did not have a clear definition of basic competencies.

It is necessary for a person to enter into personal, social, economic and professional relations in his life, to take his place in society, to solve problems, and most importantly, to be competitive in his field, profession, must have basic competencies.

1. Communicative competence;

2. Competence in working with information;

3. Competence for self-development as an individual;
4. Socially active civic competence;

5. General cultural competence;

6. Mathematical literacy, knowledge of science and technology.

The following assessment criteria can be used to assess a teacher's core competencies, depending on the type and direction of that competence:

1. Test method

2. Conversation method

3. The method of logical tasks (professional problem)

4. Written control methods

5. Pedagogical lesson observation and analysis

In addition, criteria such as knowing, explaining, interpreting, analyzing and synthesizing, evaluating, and drawing conclusions play an important role in a teacher's ability to apply basic competencies in the teaching and learning process.

\section{RESULTS}

In competency education, we can choose the methods of assessing the basic competencies in accordance with its indicators: 
The American Journal of Social Science and Education Innovations (ISSN - 2689-100x)

Published: April 30, 2021 | Pages: 670-675

Doi : https://doi.org/10.37547/tajssei/Volume03Issue04-109

2021:5.857

OCLC - 1121105668

\begin{tabular}{|c|c|c|}
\hline \hline № & Basic competencies & Evaluation methods \\
\hline 1. & Communicative competence; & Conversation method \\
\hline 2. & Competence in working with information; & Test method \\
\hline $3 \cdot$ & Competence for self-development as an individual; & $\begin{array}{c}\text { Pedagogical observation, lesson } \\
\text { analysis }\end{array}$ \\
\hline 4. & Socially active civic competence; & $\begin{array}{c}\text { Occupational issue (problematic } \\
\text { situation) }\end{array}$ \\
\hline $5 \cdot$ & & Written control method \\
\hline 6. & Mathematical literacy, knowledge of science and technology. & Logical assignments test method. \\
\hline
\end{tabular}

We can make a comparative assessment of a teacher's basic competencies in a history lesson as follows. In this case, the highest score is 50 points:

Competence in working with information (method of course analysis)

\begin{tabular}{|c|c|c|}
\hline № & Indicators & Ball \\
\hline 1. & $\begin{array}{r}\text { Use of available information sources (internet, television, radio (audio- } \\
\text { video recording), telephone, computer, e-mail, etc.); }\end{array}$ & 10 points \\
\hline 2. & $\begin{array}{r}\text { Adhere to a media culture in retrieving, sorting, processing, } \\
\text { transmitting, storing, securing and using information from the media; }\end{array}$ & 10 points \\
\hline 3. & $\begin{array}{c}\text { Ability to work with documents encountered in daily activities (be able } \\
\text { to write simple greeting cards, fill out questionnaires, write information } \\
\text { about himself in the hotel list, etc.) }\end{array}$ & 10 points \\
\hline 4. & Be able to create a database, select the basics and analyze them; & 10 points \\
\hline 5. & Know the rules of information security and be able to analyze & 10 points \\
& & information.
\end{tabular}

(Example: 6th grade history class covers topics such as ancient Egypt, Mesopotamian civilizations, Indian civilizations, Chinese civilizations, Zoroastrianism, ancient Greek culture, 7 th grade European world culture in VI-
$\mathrm{XI}$ centuries, the emergence of Islam) We assess the extent to which the researcher uses the media, how he or she analyzes today's news and information on the subject, and how 
he or she connects the topic with the media in general.)

1. Mathematical literacy, knowledge and competence in the use of scientific and technical innovations (logical task method)

\begin{tabular}{|c|c|c|}
\hline № & Indicators & Ball \\
\hline 1. & $\begin{array}{c}\text { Be able to make personal, family, professional and economic plans } \\
\text { based on accurate calculations; }\end{array}$ & 10points \\
\hline 2. & Accounting in personal, social and economic relations; & 10points \\
\hline 3. & $\begin{array}{c}\text { Read and use a variety of formulas, models, charts, graphs, and } \\
\text { diagrams in daily activities; }\end{array}$ & 10points \\
\hline $4 \cdot$ & $\begin{array}{c}\text { Be aware of and be able to use scientific and technical innovations that } \\
\text { facilitate human labor, increase productivity and create favorable }\end{array}$ & 10 copoints \\
\hline 5. & Be able to analyze statistical data & 10points \\
\hline
\end{tabular}

(For example, in the Grade 5 "Stories from History" curriculum, the teacher will teach the conversion of $A D$ and Hijri years into the years of "Map of the Year in History", "Chronology" and "History of World Maps". be able to calculate the location of a country on a map or the distance between it and another invitation, to determine what happened in the history of the world 100 years after a historical event in the history of Uzbekistan. .)

\section{CONCLUSION}

In conclusion, there are problems that need to be addressed. In particular, criteria should be developed to determine the level of competence development in students. These criteria should also take into account the age and psychophysiological characteristics of students. A lesson taught by an educator should also be a perfect lesson to follow. To do this, its structure and expertise criteria must be developed. Along with the implementation of the above tasks, it is necessary to form a scientific-methodical, information base in the educational institution, training of teaching staff, the formation of new thinking in our existing teachers.

- Introduce teachers to a competency-based approach to education;

- Acquisition of technologies that ensure the formation of basic competencies; 
- Train teachers to develop competencybased tasks and apply them in class and in extracurricular activities;

- Teach teachers to analyze and evaluate how well students have completed assignments. Be able to monitor.

- Making adjustments to one's teaching is an important part of today's education system.

\section{REFERENCES}

1. Sh.M.Mirziyoev "Critical analysis, strict discipline and personal responsibility should be a daily rule of every leader" .- Tashkent .: 2017.

2. Yusupova A.A, Kamolova S.R. Assessment of skills and competencies. Tashkent State Institute of Oriental Studies, textbook, 2012.

3. Rahimov Zokir. Pedagogical competence as an important factor in the taste process. Scientific article. Science and Education CC BY 1025128

4. Vakhobov MM "Introduction of state educational standards based on a competency approach - as a modern educational paradigm." Text of scientific articles on specialization "Nauki ob obrazovanii" CC BY 2501336.

5. Usarov JE dissertation on "Improving the content of education and developing students' competence on the basis of basic and scientific competencies (on the example of teaching physics)" https://uza.uz/uz/posts/usarov-zhabboreshbekovich -education-and-educationazaria-v-28-11-2019
6. E.E. Feyushina «Kak proydet otsenka kompetentsiy uchitelya» https://pedsovet.org/search/author/fedusin a-elvira-evgenevna

7. K. In Semenovaesa his "Program of assessment of competence of teachers: what is the term of performance" https://multiurok.ru/blog/proghrammaotsienki-kompietientsii-uchitieliei-chto-etotakoie-i-sroki-provliedi

8. Anapiyaev F. "State Education Standards based on a competency approach" (report). www.RTM.uz 